\title{
The hrp genes of Pseudomonas cichorii are essential for pathogenicity on eggplant but not on lettuce
}

\author{
Correspondence \\ Yasufumi Hikichi \\ yhikichi@cc.kochi-u.ac.jp
}

Received 2 June 2008

Revised 1 July 2008

Accepted 7 July 2008

\author{
Hiroshi Hojo, ${ }^{1}$ Makoto Koyanagi, ${ }^{1}$ Masayuki Tanaka, ${ }^{1}$ Shigeru Kajihara, ${ }^{1}$ \\ Kouhei Ohnishi, ${ }^{2}$ Akinori Kiba ${ }^{1}$ and Yasufumi Hikichi ${ }^{1}$ \\ ${ }^{1}$ Laboratory of Plant Pathology and Biotechnology, Kochi University, 200 Monobe, Nankoku, Kochi \\ 783-8502, Japan
}

${ }^{2}$ Institute of Molecular Genetics, Kochi University, 200 Monobe, Nankoku, Kochi 783-8502, Japan

\begin{abstract}
Pseudomonas cichorii causes necrotic lesions in eggplant and rot in lettuce. Through transposon insertion into $P$. cichorii strain SPC9018 we produced two mutants, 4-57 and 2-99, that lost virulence on eggplant but not lettuce. Analyses showed that a transposon was inserted into the hrpG gene in 4-57 and the hrcT gene in 2-99. Nucleotide sequences of the hrp genes of SPC9018 are homologous to those of Pseudomonas viridiflava BS group strains. The pathogenicity of 4-57 on eggplant was restored by transformation with an $h r p F$ operon, originating from either SPC9018 or the BS group member P. viridiflava strain 9504 (Pv9504). These data suggested the involvement of hrp genes in the pathogenicity of SPC9018 on eggplant, and functional conservation of hrpF operons between SPC9018 and Pv9504. Both the hrpS mutant and the hrpL mutant were unable to cause necrotic lesions on eggplant leaves but retained their pathogenicity against lettuce. These results suggest that the pathogenicity of $P$. cichorii is hrp-dependent in eggplant, but not in lettuce.
\end{abstract}

\section{INTRODUCTION}

Pseudomonas cichorii causes necrotic leaf spot on eggplants and rot on lettuce. Bacterial rot caused by the bacteria is called 'varnish spot' in California or 'tar' in Japan. The rot is characterized by shiny, dark-brown, firm necrotic spots on leaves underneath the second or the third outermost head leaves. Microscopic observations using lux-marked P. cichorii and an immunofluorescent antibody against the bacteria have shown that the bacteria first invade lettuce head leaves through stomata and then colonize intercellular spaces (Hikichi et al., 1996a, 1998). After proliferation in intercellular spaces of the mesophyll, the bacteria spread throughout the whole leaf via the vascular bundle (Hikichi et al., 1996b). The symptoms appear and develop as the bacteria multiply and spread. Our previous studies have shown that de novo protein synthesis in lettuce leaves is required for the development of disease symptoms (Hikichi et al., 1998; Kiba et al., 2006a). Moreover, the development of disease symptoms is closely associated with programmed cell death (PCD), following heterochromatin aggregation and laddering of genome DNA in the $P$. cichorii-infected lettuce

Abbreviations: PCD, programmed cell death; TTSS, type III secretion system.

The GenBank/EMBL/DDBJ accession numbers for the hrp genes of SPC9018 and the hrpF operon of Pv9504 are AB433910 and AB434833, respectively. cells (Kiba et al., 2006a). P. cichorii causes necrotic spot on eggplant, sweet pepper, celery and okra, distinct from the disease symptoms on lettuce. Kiba et al. (2006b) have shown that development of necrotic lesions following PCD on leaves of eggplants inoculated with $P$. cichorii is commonly associated with de novo protein synthesis, intracellular reactive oxygen species and caspase III-like protease activity.

In several Gram-negative phytopathogenic bacteria, the $h r p$ genes are essential determinants for disease development on compatible hosts and for elicitation of the hypersensitive response (HR) on resistant plants (Alfano \& Collmer, 1997). The hrp genes encode proteins in the type III secretion system (TTSS), which is believed to transport virulence proteins directly into the host cells. These proteins subsequently cause leakage of plant nutrients into the extracellular spaces of infected tissues and suppress host defences. Nine of the hrp genes have been renamed $h r c$ (HR and conserved) to indicate that they encode conserved components that are also present in the type III secretion machinery of the animal pathogens Yersinia, Shigella and Salmonella (Bogdanove et al., 1996). Recently Araki et al. (2006) have reported that $h r p$ genes exist in the genomic DNA of $P$. cichorii strain 83-1, but the roles of these genes in the pathogenicity of $P$. cichorii remain unclear.

In this study, we isolated two mutants that lost virulence on eggplants after transposon mutagenesis of $P$. cichorii 
strain SPC9018 (SPC9018). However, the mutants retained their virulence on lettuce. Molecular analysis revealed that the transposons were inserted in the $h r p G$ and $h r c T$ genes. Pathogenicity analysis using $h r p$ mutants showed that the $h r p$ genes of $P$. cichorii are essential for its ability to cause necrotic lesion symptoms on eggplant, but not to cause rot symptoms on lettuce.

\section{METHODS}

Bacterial strains, culture conditions and plasmids. Bacterial strains and plasmids are listed in Table 1. P. cichorii strains were routinely grown in PS medium (Wakimoto et al., 1968) at $30{ }^{\circ} \mathrm{C}$. Escherichia coli strains were grown in LM medium (Hanahan, 1983) at
$37{ }^{\circ} \mathrm{C}$. Ampicillin $\left(50 \mu \mathrm{g} \mathrm{ml}{ }^{-1}\right)$, kanamycin $\left(50 \mu \mathrm{g} \mathrm{ml}{ }^{-1}\right)$ and tetracycline $\left(30 \mu \mathrm{g} \mathrm{ml}^{-1}\right)$ were used in selective media. Populations of SPC9018 and mutants in planta were assayed in three independent experiments using PCSM plates (Uematsu et al., 1982) and PCSM plates containing kanamycin.

General DNA manipulations. Isolation of genomic DNA, plasmid DNA manipulations, PCR and Southern blot analyses were performed using standard techniques (Sambrook et al., 1989). P. cichorii was transformed by electroporation as described by Allen et al. (1991). Doublestranded DNA sequencing templates were prepared with GenElute Plasmid Miniprep kits (Sigma Chemical). Sequences were determined using an Automated DNA Sequencer model 373 (Applied Biosystems). DNA sequence data were analysed using the DNASIS-Mac software (Hitachi Software Engineering). Enzymes including restriction endonucleases (Takara) were used according to the manufacturer's instructions.

Table 1. Strains and plasmids used in this study

\begin{tabular}{|c|c|c|}
\hline Strain or plasmid & Relevant characteristics & Reference or source \\
\hline \multicolumn{3}{|l|}{ E. coli strains } \\
\hline $\mathrm{DH} 5 \alpha$ & recA1 endA1 gyrA96 thi-1 hsdR17supE44 $\Delta($ lac $)$ U169( $\phi 80$ lac $\Delta \mathrm{M} 15)$ & Takara \\
\hline SPC9018 & Wild-type & Kiba et al. (2006a) \\
\hline 2-99 & SPC9018 derivative, carries a EZ:: Tn $<\mathrm{KAN}-2>, \mathrm{Km}^{\mathrm{r}}$ & This study \\
\hline $4-57$ & SPC9018 derivative, carries a miniTn5lacZ2, $\mathrm{Km}^{\mathrm{r}}$ & This study \\
\hline SPC9018-S & hrpS-deleted mutant of SPC $9018, \mathrm{Km}^{\mathrm{r}}$ & This study \\
\hline $4-57 \mathrm{~F}$ & Transformant of 4-57 with phrpFoperon, $\mathrm{Km}^{\mathrm{r}}$, $\mathrm{Tc}^{\mathrm{r}}$ & This study \\
\hline 4-57FPV & Transformant of 4-57 with phrpFoperonPV, $\mathrm{Km}^{\mathrm{r}}, \mathrm{Tc}^{\mathrm{r}}$ & This study \\
\hline \multicolumn{3}{|l|}{ P. viridiflava strain } \\
\hline 9504 & BS type & This study \\
\hline \multicolumn{3}{|l|}{ Plasmids } \\
\hline placZ2 & P18Sfi derivative containing mini-Tn5lacZ2, $\mathrm{Km}^{\mathrm{r}}$ & de Lorenzo et al. (1990) \\
\hline pUCK191 & pUC18 derivative containing $\mathrm{Km}^{\mathrm{r}}$ from $\operatorname{Tn} 903$ & Tsuge et al. (2001) \\
\hline pUCD800 & pUCD5 derivative containing $s a c B, \mathrm{Km}^{\mathrm{r}}$ & Gay et al. (1985) \\
\hline p2-99 & $13.9 \mathrm{~kb} K p n \mathrm{I}$ fragment containing the EZ::Tn $<$ KAN-2> in pUC118 & This study \\
\hline p4-57 & $5.6 \mathrm{~kb} \mathrm{KpnI} \mathrm{fragment} \mathrm{containing} \mathrm{the} \mathrm{miniTn5lacZ2} \mathrm{in} \mathrm{pUC118} \mathrm{pGEM-T}$ & This study \\
\hline pP2-99 & 703 bp SphI- and XhoI-digested fragment of p2-99 in pUC118 & This study \\
\hline pP4-57 & $1.1 \mathrm{~kb}$ HindIII- and SmaI-digested fragment of p4-57 in pUC118 & This study \\
\hline pHOJO & $30 \mathrm{~kb}$ fragment from SPC9018 genomic DNA in pBluescript II & This study \\
\hline pKAJI & $24.3 \mathrm{~kb}$ fragment from SPC9018 genomic DNA in pBluescript II & This study \\
\hline pL3-4 & 870 bp PstI- and SacI-digested PCR fragment (3-4 fragment) in pHSG398 & This study \\
\hline phrpL & 464 bp EcoRI- and SacI-digested PCR fragment (1-2 fragment) in pL3-4 & This study \\
\hline phrpFoperon & $3.6 \mathrm{~kb}$ PCR fragment containing the $h r p F$ operon from SPC9018 genomic DNA & This study \\
\hline phrpFoperonPV & 4.1 kb PCR fragment containing the $h r p F$ operon from Pv9504 genomic DNA & This study \\
\hline
\end{tabular}


Transposon mutagenesis. To create $P$. cichorii mutants with transposon insertions, $0.5 \mu \mathrm{g}$ placZ2 (de Lorenzo et al., 1990) containing mini-Tn5lacZ2 was used for electroporation of SPC9018 competent cells. The EZ:TN transposome-mediated insertion system (Epicentre) was also used (Tsujimoto et al., 2008). The transposon $\mathrm{EZ}: \mathrm{TN}<\mathrm{KAN}-2>(0.1 \mu \mathrm{g})$ was mixed with an equal volume of $100 \%$ glycerol and $2 \mu \mathrm{l} \mathrm{EZ:TN}$ transposase $\left(1\right.$ unit $\left.\mu \mathrm{l}^{-1}\right)$, and incubated at $37^{\circ} \mathrm{C}$ for $10 \mathrm{~min}$. Aliquots $(1 \mu \mathrm{l})$ were used for electroporation of $P$. cichorii. Transposition clones were selected by plating on PS medium containing kanamycin.

Transposon-inserted site in genomic DNA of mutants. To determine whether a single transposon insertion had occurred in the genome of mutants 2-99 and 4-57 through the insertion by EZ:: Tn $<\mathrm{KAN}-2>$ and mini-Tn5lacZ2, respectively, their genomic DNAs were isolated using the AquaPure Genomic DNA Isolation kit (BioRad). DNA from 2-99 was digested with EcoRI, 4-57 DNA was digested with XhoI, and the DNA fragments were then separated by agarose gel electrophoresis and hybridized with $\mathrm{Km}^{\mathrm{R}}$ from EZ: : Tn $<\mathrm{KAN}-2>$ (2-99) and $\mathrm{Km}^{\mathrm{R}}$ from pUCK191 (4-57) (Tsuge et al., 2001).

The KpnI fragments from genomic DNA of the mutants were ligated into the plasmid vector pUC118 (Takara), and the resulting plasmids were transformed into E. coli DH5 $\alpha$ (Takara). Kanamycin-resistant transformants were isolated. Each harboured plasmid p2-99 or p4-57, which contained 13.9 or $5.6 \mathrm{~kb}$ DNA fragments from genomic DNA of 2-99 and 4-57, respectively. The inserts carried on p2-99 and p4-57 were also sequenced.

Determination of the nucleotide sequence of the hrp cluster. To create a genomic library of SPC9018, genomic DNA from SPC9018 was isolated and partially digested by Sau3AI. DNA fragments $(10-20 \mathrm{~kb})$ were collected by sucrose density-gradient centrifugation (Kanda et al., 2003). The DNA fragments were ligated into the BamHI site of pBluescript II KS+ (Stratagene), and transformed into E. coli $\mathrm{DH} 5 \alpha$, to create a genomic library of SPC9018.

A 703 bp SphI- and XhoI-digested fragment of p2-99, and a $1.1 \mathrm{~kb}$ HindIII- and SmaI-digested fragment of p4-57 were ligated into pUC118 to create plasmids pP2-99 and pP4-57, respectively. The plasmids were used as templates in PCRs. Southern blot hybridization was performed using DIG-labelled DNA probes (Roche Molecular Biochemicals) to probe the hrp cluster from the SPC9018 genomic library. The DIG-labelled probes were PCR-amplified with M4 (5' GTTTTCCCAGTCACGAC-3') and RV (5'-CAGGAAACAGCTATGAC-3') according to the manufacturer's protocol. The resultant positive transformant hrpG-posi harboured the plasmid pHOJO containing a $30 \mathrm{~kb}$ insert. The other positive transformant, hrcT-posi, harboured pKAJI containing a $24.3 \mathrm{~kb}$ insert. These were used to sequence the hrp cluster.

Complementation of 4-57 with $\boldsymbol{h r p F}$ operons. A $3.6 \mathrm{~kb}$ fragment was PCR-amplified from the genomic DNA of SPC9018 with the following primers: 5'-GCTCTAGAGGGTCAACTGGGCTGGACGTTG-3' (named Xba-FW-hrpFoperon) with an added XbaI site (underlined) and $5^{\prime}$-GCTCTAGATGCGCGTCGCGTTGAGAGTTCG-3' (named Xba-RV-hrpFoperon) with an added XbaI site (underlined). PCR amplification was performed with 1 cycle of $94{ }^{\circ} \mathrm{C}$ for $2 \mathrm{~min}, 5$ cycles of $94{ }^{\circ} \mathrm{C}$ for $1 \mathrm{~min}, 62^{\circ} \mathrm{C}$ for $1 \mathrm{~min}$, and $72{ }^{\circ} \mathrm{C}$ for $3 \mathrm{~min}, 20$ cycles of $94{ }^{\circ} \mathrm{C}$ for $1 \mathrm{~min}, 65^{\circ} \mathrm{C}$ for $1 \mathrm{~min}$, and $72{ }^{\circ} \mathrm{C}$ for $3 \mathrm{~min}$. The $\mathrm{XbaI}$-digested fragment was ligated into the XbaI site of pLAFR3 (Staskawicz et al., 1987), and phrpFoperon was created. A $4.1 \mathrm{~kb}$ fragment was PCR-amplified from the genomic DNA of Pseudomonas viridiflava strain 9504 (Pv9504), which belongs to the BS group, with the following primers: 5'-GCTCTAGACTCATGTTGACCCGTCGCAGTC-3' (named Xba-PV-FW-hrpFoperon) with an added $\mathrm{XbaI}$ site (underlined) and $5^{\prime}$-GCTCTAGAGCATGTCGCGTTGGGAGTTCGC-3' (named Xba-PV-RV-hrpFoperon) with an added $X b a \mathrm{I}$ site (underlined), based on the nucleotide sequences of $P$. viridiflava strains ME3.1b, RMX23.1a and RMX3.1b (Araki et al., 2006). PCR amplification was performed with 1 cycle of $94{ }^{\circ} \mathrm{C}$ for $2 \mathrm{~min}, 5$ cycles of $94{ }^{\circ} \mathrm{C}$ for $1 \mathrm{~min}, 60{ }^{\circ} \mathrm{C}$ for $1 \mathrm{~min}$, and $72{ }^{\circ} \mathrm{C}$ for $3 \mathrm{~min}, 20$ cycles of $94{ }^{\circ} \mathrm{C}$ for $1 \mathrm{~min}, 65^{\circ} \mathrm{C}$ for $1 \mathrm{~min}$, and $72{ }^{\circ} \mathrm{C}$ for $3 \mathrm{~min}$. The $\mathrm{XbaI}$-digested fragment was ligated into the $X b a I$ site of pLAFR3, and phrpFoperonPV was created. phrpFoperon and phrpFoperonPV were transformed into 4-57 competent cells, and the tetracycline-resistant transformants $4-57 \mathrm{~F}$ and $4-57 \mathrm{FPV}$ were created, respectively.

Creation of $\boldsymbol{h r p} \boldsymbol{L}$ and $\boldsymbol{h r p S}$ mutants. An $870 \mathrm{bp}$ fragment (named 3-4) was PCR-amplified from the genomic DNA of SPC 9018 with the following primers: 5'-CAGCCCTGCAGAACGCTAAC-3' (named 4Pst) and 5'-CGAGCTCTGAACAGTTTTGTCCC-3' (named 3-Sac) with an added SacI site (underlined). PCR amplification was performed with 1 cycle of $94{ }^{\circ} \mathrm{C}$ for 2 min, 5 cycles of $94{ }^{\circ} \mathrm{C}$ for $1 \mathrm{~min}, 50{ }^{\circ} \mathrm{C}$ for $1 \mathrm{~min}$, and $72{ }^{\circ} \mathrm{C}$ for $1 \mathrm{~min}, 20$ cycles of $94{ }^{\circ} \mathrm{C}$ for $1 \mathrm{~min}, 55^{\circ} \mathrm{C}$ for $1 \mathrm{~min}$, and $72{ }^{\circ} \mathrm{C}$ for $1 \mathrm{~min}$. The SacI- and PstIdigested 3-4 fragment was ligated into the SacI and PstI sites of pHSG398 (Takara), and pL3-4 was created. A 464 bp fragment (named 1-2) was PCR-amplified from the genomic DNA of SPC9018 with the following primers: 5'-GGAATTCGGGGCGTTCCACGCTTTC-3' (named 1-RI) with an added EcoRI site (underlined) and 5' GGGAGCTCGGTCACTGCATGCCTTTGACTTC-3' (named 2-Sac) with an added SacI site (underlined). PCR amplification was performed with 1 cycle of $94{ }^{\circ} \mathrm{C}$ for 2 min, 5 cycles of $94{ }^{\circ} \mathrm{C}$ for $1 \mathrm{~min}, 50{ }^{\circ} \mathrm{C}$ for $1 \mathrm{~min}$, and $72{ }^{\circ} \mathrm{C}$ for $30 \mathrm{~s}, 20$ cycles of $94{ }^{\circ} \mathrm{C}$ for $1 \mathrm{~min}, 55^{\circ} \mathrm{C}$ for $1 \mathrm{~min}$, and $72{ }^{\circ} \mathrm{C}$ for $30 \mathrm{~s}$. The EcoRI- and SacIdigested 1-2 fragment was ligated into the EcoRI and SacI sites of pL34 , and phrpL was created. A $1.4 \mathrm{~kb} K p n \mathrm{I}$-digested fragment of pUCK191 containing $\mathrm{Km}^{\mathrm{R}}$ was blunt-ended by T4 DNA polymerase and ligated into the blunt-ended phrpL SacI site to create p398-LKm. A $2.6 \mathrm{~kb}$ PstI- and BamHI-digested DNA fragment containing $s a c B$ from pUCD800 (Gay et al., 1985) was blunt-ended by T4 DNA polymerase and ligated into the blunt-ended p398-LKm EcoRI site to create p398-LKmsac. This plasmid was electroporated into SPC9018 cells and the resulting kanamycin- and sucrose-resistant recombinant, SPC9018-L, was selected. Southern blot analysis was performed to verify correct insertion of the $2.7 \mathrm{~kb}$ fragment containing $\mathrm{Km}^{\mathrm{R}}$ into the $h r p L$ locus in the genetic backgrounds isolated (data not shown), and this showed that SPC9018-L was an hrpL-deficient mutant of SPC9018.

A $4.7 \mathrm{~kb}$ EcoRI- and SmaI-digested fragment of pHOJO was ligated into the EcoRI and SmaI sites of pHSG398, and p398-S was created. A $1.4 \mathrm{~kb} \mathrm{KpnI-digested} \mathrm{fragment} \mathrm{of} \mathrm{pUCK191} \mathrm{containing} \mathrm{Km}^{\mathrm{R}}$ was blunt-ended by T4 DNA polymerase and inserted into the the p398-S EcoRV site to create p398-SKm. A $2.6 \mathrm{~kb} \mathrm{BamHI-}$ and PstI-digested DNA fragment containing $s a c B$ from pUCD800 was blunt-ended by T4 DNA polymerase and ligated into the blunt-ended p398-SKm EcoI site to create p398-SKmsac. This plasmid was electroporated into SPC9018 cells and the resultant kanamycin- and sucrose-resistant recombinant, SPC9018-S, was selected. Southern blot analysis was performed to verify correct insertion of the $6.1 \mathrm{~kb}$ fragment containing $\mathrm{Km}^{\mathrm{R}}$ in the $h r p S$ locus in the genetic backgrounds isolated (data not shown), showing that SPC9018-S was an hrpS-deficient mutant of SPC9018.

Virulence assays. Eggplant (Solanum melongena L. cv. Senryo no. 2), lettuce (Lactuca sativa L. cv. Success), celery (Apium graveolens L. cv. Topseller), sweet pepper (Capsicum annuum cv. Shosuke) and okra plants (Abelmoschus esculentus cv. Gulliver) were grown in pots containing commercial soil (Tsuchitaro, Sumitomo Forestry) in a growth room at $25^{\circ} \mathrm{C}$. Light $\left(16 \mathrm{~h} \mathrm{day}^{-1}\right)$ was supplied at 10000 lux 
throughout the experimental period. Five-week-old test plants were inoculated by leaf infiltration using a $1 \mathrm{ml}$ disposable syringe with $1.0 \times 10^{8}$ c.f.u. $\mathrm{ml}^{-1}$ bacteria in a $20 \mu \mathrm{l}$ volume. For all assays, inoculum concentrations were determined spectrophotometrically and confirmed by dilution plating. Lettuce plants were coded and inspected for symptoms daily for 7 days after inoculation. Plants were rated on a zero-to-three disease index scale: 0, no symptoms; 1, discolouring; 2, browning; 3, collapse. Other plants were coded and inspected for symptoms daily for 7 days after inoculation. Plants were rated on a zero-to-three disease index scale: 0, no symptoms; 1 , discolouring at inoculated sites; 2, necrosis at inoculated sites; 3 , necrosis at the periphery of the inoculate sites. Within each trial, 12 plants of each strain were treated, yielding 60 plants per strain.

Bacterial population in planta. Areas $\left(1 \mathrm{~cm}^{2}\right)$ inoculated with $P$. cichorii strains were excised from eggplant and lettuce leaves of five plants at $0,1,2$ and 3 days after inoculation and ground using a mortar and pestle. Samples $(0.1 \mathrm{ml})$ of the original solution and 10 fold serial dilutions thereof were spread onto three plates of selective agar media of PCSM (Uematsu et al., 1982) for SPC9018, media containing $50 \mu \mathrm{g}$ kanamycin $\mathrm{ml}^{-1}$ for SPC9018-L and 4-57, and media containing $50 \mu \mathrm{g}$ kanamycin $\mathrm{ml}^{-1}$ and $30 \mu \mathrm{g}$ tetracycline $\mathrm{ml}^{-1}$ for 4-57F. Colonies were counted after 2 days of incubation at $30{ }^{\circ} \mathrm{C}$ to estimate the population.

\section{RESULTS}

\section{Selection of mutants losing virulence on eggplant}

SPC9018 caused necrotic lesions (Fig. 1a) on eggplant and rot on lettuce (Fig. 1b) within 3 days after inoculation (Fig. 2). In total, 849 and 731 transposon mutants were derived from SPC 9018 by random EZ:: Tn $<\mathrm{KAN}-2>$ and mini-Tn5-insertion, respectively. We selected two mutants, 2-99 and 4-57, that were unable to cause necrotic lesions on eggplant within 7 days of inoculation (Fig. 1a). However, the mutants retained their ability to cause rot on lettuce leaves, although rot symptoms caused by the mutants were delayed compared to those caused by SPC9018 (Fig. 2). Other mutants retained similar virulence to SPC9018 against both eggplant and lettuce.

\section{Cloning of the transposon-containing fragment from mutants}

In Southern analysis a single transposon insertion was observed in the DNA of 2-99 and 4-57 (data not shown). No hybridization signal was observed in the DNA of parental strain SPC9018. The KpnI-digested 13.9 and $5.6 \mathrm{~kb}$ fragments containing the inserted region of transposons from the genomes of 2-99 and 4-57 were cloned into pUC118, and p2-99 and p4-57 were created, respectively. The nucleotide sequences of inserted fragments showed that the transposons were inserted into the hrcT gene in p2-99 and the hrpG gene in p4-57 (Fig. 3).

\section{Sequence analysis of the hrp cluster}

The Sau3AI-digested 30.0 and $24.3 \mathrm{~kb}$ fragments containing $h r p G$ and $h r c C$ from the genome of SPC9018 were cloned into pBluescript II KS +, and pHOJO and pKAJI were created, respectively. Inserts of pHOJO and pKAJI were sequenced and ORFs were analysed based on the nucleotide sequence of $h r p$ genes in 83-1. Analyses of nucleotide sequences of the 30.0 and $24.3 \mathrm{~kb}$ inserts showed that the DNA region including the $h r p$ cluster of SPC9018 consisted of 49 ORFs. These ORFs were divided into four regions: A, B, C and D (Table 2, Fig. 3).

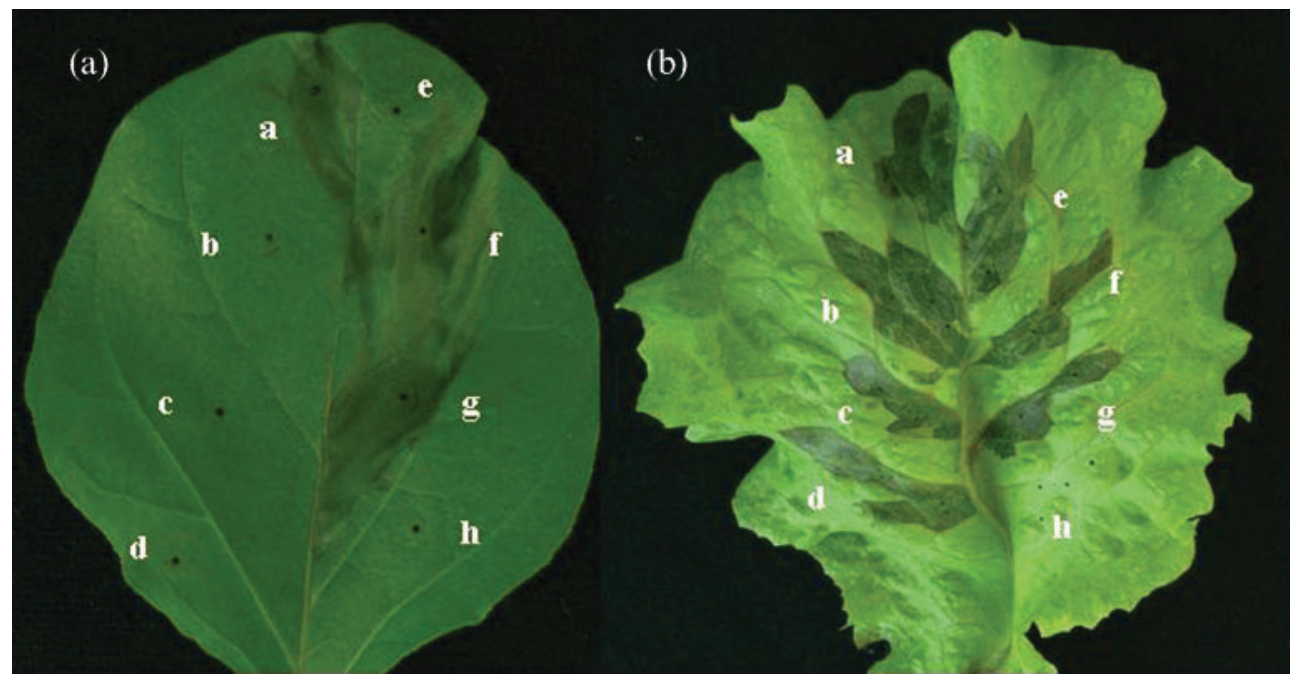

Fig. 1. Necrotic lesions on eggplant leaves (a) and rot on lettuce leaves (b) after inoculation with $P$. cichorii strains. Five-weekold plants were inoculated by leaf infiltration with $P$. cichorii strains. a, SPC9018; b, 2-99; c, 4-57; d, SPC9018-S; e, SPC9018-L; f, 4-57F; g, 4-57FPV. Inoculates consisted of $1.0 \times 10^{8}$ c.f.u. $\mathrm{ml}^{-1}$ bacteria and distilled water (h) in a $20 \mu \mathrm{l}$ volume. Plants were grown in a growth room at $25{ }^{\circ} \mathrm{C}$ (10000 lux, $16 \mathrm{~h}$ per day) for 3 days. 


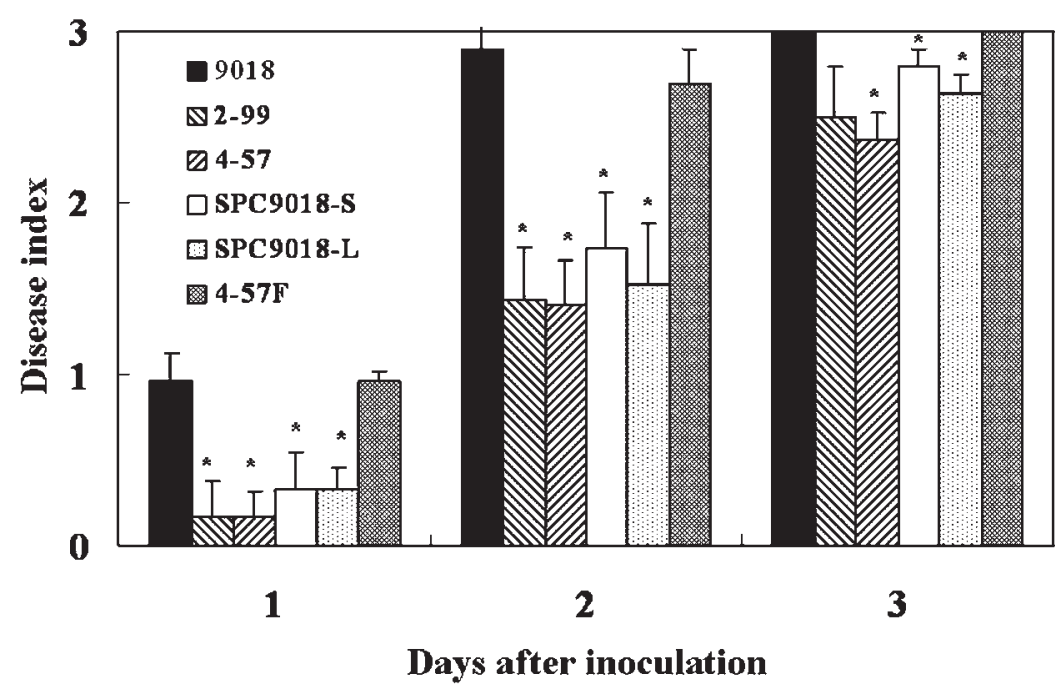

Fig. 2. Virulence of $P$. cichorii strains on lettuce. Values represent the mean \pm SD of five separate experiments. Asterisks denote values significantly different from the disease index of inoculation with $P$. cichorii strain SPC9018 $\left({ }^{\star} P<0.05\right)$.
Fifteen ORFs were present in region A $(14.7 \mathrm{~kb})$. These encoded a LysR family transcriptional regulator, aldehyde dehydrogenase, phosphinothrin $\mathrm{N}$-acetyltransferase, HrpL, HrpJ, HrcV, HrpQ, HrcN, HrpO, HrpP, HrcQ, HrcR, HrcS, HrcT and HrcU. Each ORF (Table 2, Fig. 3) was preceded by a ribosome-binding site. Region $\mathrm{B}(17.2 \mathrm{~kb})$ included 17 ORFs encoding HrpS, HrpA, HrpZ, HrpB, HrcJ, HrpD, HrpE, HrpF, HrpG, HrcC, HrpT, HrpV, AvrF, HrpW, HrpW-specific chaperone, asparaginyl beta-hydroxylase and AvrE. Nucleotide sequences and alignments of these ORFs located in regions A and B showed homology to those of 83-1 and P. viridiflava BS-type strain RMX3.1b. Comparison to 83-1 sequences (Araki et al., 2006) showed that the consensus sequence of the $h r p$ box may be

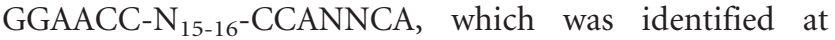
84 bp upstream of hrpA, 31 bp upstream of $h r p F, 135 \mathrm{bp}$ upstream of $h r p W, 79 \mathrm{bp}$ upstream of avrF and $61 \mathrm{bp}$ upstream of hrpJ. Putative Rho-independent terminators were located between $h r p S$ and $h r p A$ and between $h r p L$ and the phosphinothricin $\mathrm{N}$-acetyltransferase gene, but no others were found.

Region C (14.8 kb) was located between region A and region B, and contained 14 ORFs (Table 2, Fig. 3). Nucleotide sequences of 12 ORFs, C1-C12, were homologous to those of CV_1407CV_1396 of Chromobacterium violaceum strain ATCC 12472 (Brazilian National Genome Project Consortium, 2003). Furthermore, nucleotide sequences of $\mathrm{C} 14$ were homologous to those of Pput1855 of Pseudomonas putida strain F1. In comparison with region C of $P$. cichorii strain 83-1, one ORF, C13, existed in SPC9018 alone. The nucleotide sequence of C13 at position 94-825 showed homology to the PSPTO_3183encoded pirin from Pseudomonas syringae pv. tomato strain DC3000 at position 31-762 (Buell et al., 2003). The nucleotide sequence of $\mathrm{C} 13$ at 1196-1569 showed homology to the Xcc0038-encoded FND-dependent NADH azoreductor from Xanthomonas campestris pv. campestris strain ATCC 33913 at position 347-720 (da Silva et al., 2002).

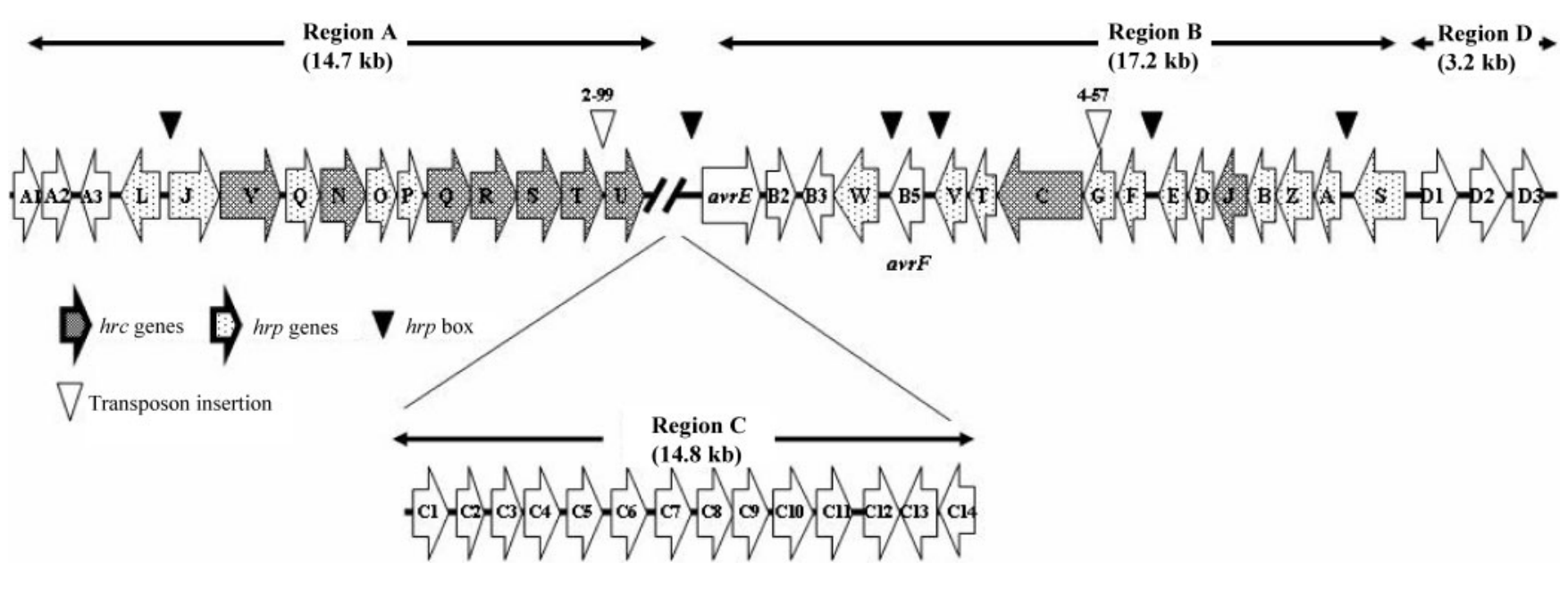

Fig. 3. Assembly of ORFs of the DNA region that includes the hrp genes of $P$. cichorii strain SPC9018 genomic DNA. 
Table 2. Homologues of open reading frames in $A, B, C$ and $D$ regions of pathogenicity islands of $P$. cichorii strain SPC9018

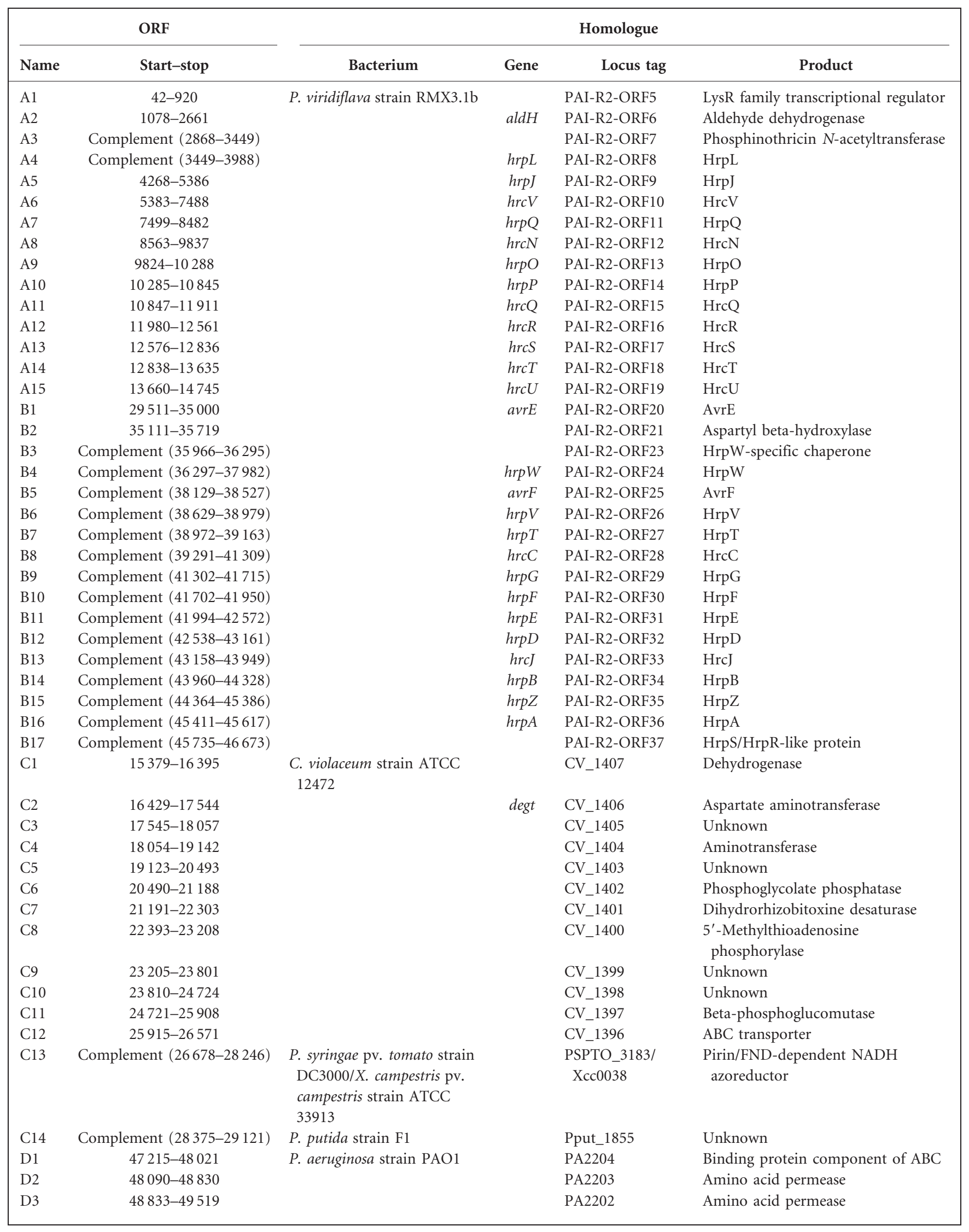


Three ORFs were present in region $\mathrm{D}(3.2 \mathrm{~kb})$, encoding two amino acid permeases and the binding protein component of an $\mathrm{ABC}$ transporter, which showed homology to those of Pseudomonas aeruginosa strain PAO1 (Stover et al., 2000) (Table 2, Fig. 3).

\section{Complementation of 4-57 with the hrpF operon}

To confirm the involvement of the TTSS in P. cichorii virulence against eggplant, the $h r p T$ mutant with the transposon insertion 4-57 was transformed with a plasmid carrying the $h r p F$ operons from the SPC9018 genome. The transformant 4-57F (Figs 1a and 2) showed virulence against both eggplant and lettuce plants, similar to SPC9018. Furthermore, 4-57 was transformed with phrpFoperonPV containing the $h r p F$ operon from the Pv9504 genome, and the transformant 4-57FPV was created (Fig. 2). 4-57FPV showed virulence against both eggplant and lettuce plants. These results suggest that the $h r p F$ operon is involved in the virulence of SPC9018 against eggplant, and that the $h r p F$ operon from $\mathrm{Pv} 9504$ is functional in SPC9018.

\section{Virulence of hrpL and hrpS mutants}

To analyse the involvement of $h r p S$ and $h r p L$ in the pathogenicity of SPC9018, hrpS- and hrpL-deficient mutants were created. Both the hrpS- and the hrpLdeficient mutants lost their virulence on eggplant, in a manner similar to 2-99 and 4-57 (Fig. 1a). Both the $h r p S$ mutant and the $h r p L$ mutant retained their virulence on lettuce leaves, although rot symptoms caused by the mutants were delayed compared to those caused by SPC9018 (Figs 1b and2). All hrp mutants lost their virulence on celery, okra and sweet pepper.

\section{Population of $\boldsymbol{P}$. cichorii strains in eggplant and lettuce leaves}

Populations of 4-57 and the hrpL-deficient mutant SPC9018-L showed little change after inoculation into eggplant leaves, remaining at $1.4 \times 10^{4}-3.2 \times 10^{4}$ c.f.u. $\mathrm{cm}^{-2}$ at 3 days after inoculation. On the other hand, 1 day after inoculation the parent strain reached its maximum population size of $2.3 \times 10^{6}$ c.f.u. $\mathrm{cm}^{-2}$, and $4-57 \mathrm{~F}$ reached its maximum of $3.4 \times 10^{6}$ c.f.u. $\mathrm{cm}^{-2}$ (Fig. 4a).

SPC9018 and 4-57F grew vigorously in lettuce leaves, and reached $4.3 \times 10^{6}$ and $5.2 \times 10^{6}$ c.f.u. $\mathrm{cm}^{-2}$ respectively, by 1 day after inoculation. 4-57 and SPC9018-L grew more slowly in lettuce leaves than the parent strain, and reached population sizes of $2.4 \times 10^{6}$ and $1.7 \times 10^{6}$ c.f.u. $\mathrm{cm}^{-2}$, respectively, by 2 days after inoculation (Fig. $4 \mathrm{~b}$ ).

The parental and the mutant strains grew similarly in both PS medium and PCSM medium (data not shown).

\section{DISCUSSION}

Lettuce leaf tissues inoculated with $P$. cichorii show browning and collapse symptoms. $P$. cichorii also causes necrotic leaf spots and induces cell death in eggplant. Our previous studies showed that there may be differences not only in the induction kinetics and level of plant responses, but also in the infection-related responses between bacterial rot in lettuce leaves and necrotic leaf spots in eggplant leaves (Kiba et al., 2006a, b). The results of the present study showed that the hrp-deficient mutants lost their ability to grow vigorously in eggplant leaves and also their virulence towards eggplant, indicating that the virulence of $P$. cichorii towards eggplant is dependent (a)

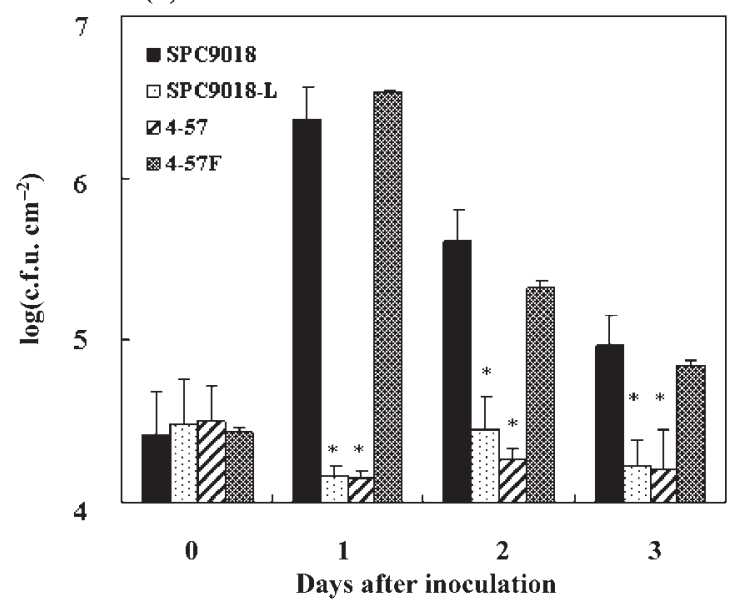

(b)

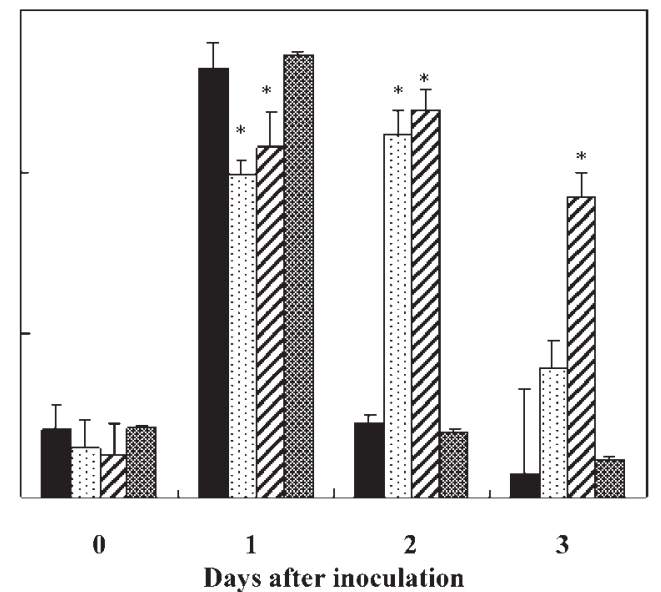

Fig. 4. Population dynamics of $P$. cichorii strains in infiltrated eggplant leaves (a) and lettuce leaves (b). Values represent the mean \pm SD of five separate experiments. Asterisks denote values significantly different from the population of $P$. cichorii strain SPC9018 ( $\left.{ }^{*} P<0.05\right)$. 
upon the $h r p$ genes. On the other hand, the $h r p$-deficient mutants retained their virulence towards lettuce. Therefore, the virulence functions of $P$. cichorii in lettuce differ from those in eggplant.

The nucleotide sequences of the $P$. cichorii hrp genes and their genetic structure were homologous to those of $P$. viridiflava BS group strains, suggesting a common ancestor of hrp clusters between $P$. viridiflava BS group strains and $P$. cichorii strains. $P$. viridiflava harbours two structurally distinct and highly diverged pathogenicity island (PAI) paralogues, T-PAI and S-PAI. These paralogues are integrated at different chromosome locations in the genome of $P$. viridiflava AT group strains, and AS group and BS group strains, respectively (Araki et al., 2006). Phylogenetic analysis showed that the time of the most recent common ancestor of T-PAI and S-PAI predates the split of $P$. viridiflava from other Pseudomonas species. This indicates that one of the PAIs cannot have originated as a recent duplication event of the other, and a recent horizontal gene transfer cannot explain the presence/ absence polymorphism of S-PAI or T-PAI. Phylogenetic analysis using nucleotide sequences of $g y r B$ and $r p o D$ demonstrates that within the ' $P$. syringae complex', $P$. cichorii strains form an independent monophyletic cluster with two strains of $P$. syringae pv. syringae (Yamamoto et al., 2000). Our preliminary phylogenetic analysis using nucleotide sequences of $h r p L$ and $h r p S / h r p A$ also showed that 12 strains of $P$. cichorii, including SPC9018 and 83-1, form a monophyletic cluster independent of $P$. viridiflava and P. syringae (data not shown). It was thus thought that the time of the most recent common ancestor between SPAI of $P$. viridiflava and the hrp clusters of $P$. cichorii may predate the split of $P$. cichorii from other Pseudomonas species. The ORFs $\mathrm{C} 1-\mathrm{C} 12$ and $\mathrm{C} 14$ in region $\mathrm{C}$ may have been acquired subsequently in common with $C$. violaceum and $P$. putida, respectively. The existence of ORF $\mathrm{C} 13$ in SPC 9018 but not 83-1 suggests diversity among P. cichorii strains.

There are distinct differences in virulence and hostspecificity between AT group strains, and AS and BS group strains of $P$. viridiflava. Araki et al. (2006) have suggested that these differences may be maintained by selection as alternative means of interacting with different hosts. The host range of $P$. cichorii differs from that of $P$. viridiflava, although both pathogens infect lettuce and okra. The $h r p F$ operon from $P$. viridiflava BS group strain 9504 was able to complement the virulence of $h r p G$ mutants on eggplants, suggesting functional conservation of $h r p F$ operons between SPC9018 and Pv9504. Comparing SPC9018 and P. viridiflava strain RMX3.1b, the amino acid sequence identities of the TTSS-dependent effectors AvrE and HrpW were 33.6 and $61.8 \%$, respectively (data not shown). Furthermore, the hrp mutants of SPC9018 lost their ability to cause necrotic spots on not only eggplant but also celery, sweet pepper and okra. Therefore, after acquisition of the the DNA region that includes the $h r p$ genes, variation of TTSS effector genes under valance selection may lead to the acquisition by $P$. cichorii of virulence against eggplant, celery, sweet pepper and okra. This would result in differences of virulence between $P$. cichorii and the $P$. viridiflava BS group. However, the roles of these candidates in bacterial virulence remain unclear.

The need for an hrp gene for virulence has been documented in both non-macerating plant pathogens and in macerating Erwinia spp. and Pectobacterium spp. In the soft-rot pathogens, $h r p N_{E c h}$ mutants are weakly pathogenic on chicory (Bauer et al., 1994, 1995), whereas $h r p N_{E c c}$ mutants are fully pathogenic on host plants (Cui et al., 1996). Furthermore, plants infected with an hrcC mutant of Pectobacterium (Erwinia) carotovora subsp. carotovora show delayed symptom development (Rantakari et al., 2001). Lehtimäki et al. (2003) have reported that high basal-level expression of $h r p$-regulated genes in Pectobacterium (Erwinia) carotovora subsp. carotovora has a negative impact on disease progress in the susceptible host plant Arabidopsis thaliana. The macerating enzymic bombardment launched by the necrotrophic Erwinia spp. and Pectobacterium spp. is a robust method of invasion compared with biotrophic bacterial species, which depend fully on the $h r p$ gene functions for virulence. Although biotrophic pathogens also carry additional virulence determinants such as genes for toxins and extracellular polysaccharides, they are nonvirulent without the TTSS, at least under laboratory conditions. Therefore, the effect of the TTSS differs between necrotrophic and biotrophic pathogens. P. cichorii induces PCD in eggplant leaves, leading to development of necrotic leaf spots (Kiba et al., 2006b). The hrp-deficient mutants lost their ability to grow vigorously in eggplant leaves and also their virulence on eggplants, suggesting that the bacteria have a biotrophic interaction with eggplants. SPC9018 grows vigorously in intercellular spaces after invasion through stomata in lettuce leaves. This leads to induction of PCD, resulting in induction of collapse and browning symptoms (Hikichi et al., 1998; Kiba et al., 2006a). Although the hrp-deficient mutants of SPC9018 retained their virulence on lettuce plants, the mutants grew more slowly, and the appearance of disease symptoms on infected lettuce leaves was delayed compared with the wildtype strain. Our data suggest that the bacteria have a more necrotrophic interaction with lettuce, and the $h r p$ cluster plays a role in virulence at the early stages of infection into lettuce leaves, although the $h r p$ genes are not directly implicated in induction of PCD. Therefore, after introduction into $P$. cichorii by horizontal gene transfer, the putative TTSS-dependent effector proteins may hinder or delay the plant defence response, giving the bacteria time to multiply before inducing PCD in lettuce leaves.

\section{ACKNOWLEDGEMENTS}

This work was supported by Grants-in-Aid for Scientific Research awarded to Y.H. (16380037, 20380029), A. K. (16780031, 18780029) and K. O. (17380031) from the Ministry of Education, Science, Sports 
and Culture, Japan, and a grant from the Asahi Glass Foundation to A. K.

\section{REFERENCES}

Alfano, J. R. \& Collmer, A. (1997). The type III (Hrp) secretion pathway of plant pathogenic bacteria; trafficking harpins, avr proteins, and death. J Bacteriol 179, 5655-5662.

Allen, C., Huang, Y. \& Sequeira, L. (1991). Cloning of genes affecting polygalacturonase production in Pseudomonas solanacearum. Mol Plant Microbe Interact 4, 147-154.

Araki, H., Tian, D., Goss, E. M., Jakob, K., Halldorsdottir, S. S., Kreitman, M. \& Bergelson, J. (2006). Presence/absence polymorphism for alternative pathogenicity islands in Pseudomonas viridiflava, a pathogen of Arabidopsis. Proc Natl Acad Sci U S A 103, 5887-5892.

Bauer, D. W., Bogdanove, A. J., Beer, S. V. \& Collmer, A. (1994). Erwinia chrysanthemi hrp genes and their involvement in soft rot pathogenesis and elicitation of the hypersensitive response. Mol Plant Microbe Interact 7, 573-581.

Bauer, D. W., Wei, Z. M., Beer, S. V. \& Collmer, A. (1995). Erwinia chrysanthemi harpinEch: an elicitor of the hypersensitive response that contributes to soft-rot pathogenesis. Mol Plant Microbe Interact 8, 484-491.

Bogdanove, A. J., Beer, S. V., Bonas, U., Boucher, C. A., Collmer, A., Coplin, D. L., Cornelis, G. R., Huang, H. C., Hutcheson, S. W. \& other authors (1996). Unified nomenclature for broadly conserved $h r p$ genes of phytopathogenic bacteria. Mol Microbiol 20, 681-683.

Brazilian National Genome Project Consortium (2003). The complete genome sequence of Chromobacterium violaceum reveals remarkable and exploitable bacterial adaptability. Proc Natl Acad Sci U S A 100, 11660-11665.

Buell, C. R., Joardar, V., Lindeberg, M., Selengut, J., Paulsen, I. T., Gwinn, M. L., Dodson, R. J., Deboy, R. T., Durkin, A. S. \& other authors (2003). The complete genome sequence of the Arabidopsis and tomato pathogen Pseudomonas syringae pv. tomato DC3000. Proc Natl Acad Sci U S A 100, 10181-10186.

Cui, Y., Madi, L., Mukherjee, A., Dumenyo, C. K. \& Chatterjee, A. K. (1996). The RsmA-mutants of Erwinia carotovora subsp. carotovora strain Ecc71 overexpress $h r p N E c c$ and elicit a hypersensitive reactionlike response in tobacco leaves. Mol Plant Microbe Interact 9, 565-573.

da Silva, A. C., Ferro, J. A., Reinach, F. C., Farah, C. S., Furlan, L. R., Quaggio, R. B., Monteiro-Vitorello, C. B., Van Sluys, M. A., Almeida, N. F. \& other authors (2002). Comparison of the genomes of two Xanthomonas pathogens with differing host specificities. Nature 417, 459-463.

de Lorenzo, V., Herrero, M., Jakubzik, U. \& Timmis, K. N. (1990), Mini-Tn 5 transposon derives for insertion mutagenesis, promoter probing, and chromosomal insertion of cloned DNA in Gramnegative Eubacteria. J Bacteriol 172, 6568-6572.

Gay, P., Le Coq, D., Steinmetz, M., Berkelman, T. \& Kado, C. I. (1985). Positive selection procedure for entrapment of insertion sequence elements in Gram-negative bacteria. J Bacteriol 164, 918921.

Hanahan, D. (1983). Studies on transformation of Escherichia coli with plasmids. J Mol Biol 166, 557-580.

Hikichi, Y., Saito, A. \& Suzuki, K. (1996a). Infection sites of Pseudomonas cichorii into head leaf of lettuce. Ann Phytopathol Soc Jpn 62, 125-129.

Hikichi, Y., Saito, A. \& Suzuki, K. (1996b). Relationship between population dynamics of Pseudomonas cichorii on lettuce and disease incidence of bacterial rot of lettuce. Ann Phytopathol Soc Jpn 62, $141-146$.

Hikichi, Y., Suzuki, K., Toyoda, K., Horikoshi, M., Hirooka, T. \& Okuno, T. (1998). Successive observation of growth and movement of genetically lux-marked Pseudomonas cichorii and the response of host tissues in the same lettuce leaf. Ann Phytopathol Soc Jpn 64, 519-525.

Kanda, A., Yasukohchi, M., Ohnishi, K., Kiba, A., Okuno, T. \& Hikichi, Y. (2003). Ectopic expression of Ralstonia solanacearum effector protein PopA early in invasion results in loss of virulence. Mol Plant Microbe Interact 16, 447-455.

Kiba, A., Sangawa, Y., Ohnishi, K., Yao, N., Park, P., Nakayashiki, H., Tosa, Y., Mayama, S. \& Hikichi, Y. (2006a). Induction of apoptotic cell death leads to the development of bacterial rot caused by Pseudomonas cichorii. Mol Plant Microbe Interact 19, 112-122.

Kiba, A., Takata, O., Ohnishi, K. \& Hikichi, Y. (2006b). Comparative analysis of induction pattern of programmed cell death and defenserelated responses during hypersensitive cell death and development of bacterial necrotic leaf spots in eggplant. Planta 224, 981-994.

Lehtimäki, S., Rantakari, A., Routtu, J., Tuikkala, A., Li, J., Virtaharju, O., Palva, E. T., Romantschuk, M. \& Saarilahti, H. T. (2003). Characterization of the hrp pathogenicity cluster of Erwinia carotovora subsp. carotovora: high basal level expression in a mutant is associated with reduced virulence. Mol Genet Genomics 270, 263-272.

Rantakari, A., Virtaharju, O., Vahamiko, S., Taira, S., Palva, E. T., Saarilahti, H. T. \& Romantschuk, M. (2001). Type III secretion contributes to the pathogenesis of the soft-rot pathogen Erwinia carotovora: partial characterization of the hrp gene cluster. Mol Plant Microbe Interact 14, 962-968.

Sambrook, J., Fritsch, E. F. \& Maniatis, T. (1989). Molecular Cloning: a Laboratory Manual, 2nd edn. Cold Spring Harbor, NY: Cold Spring Habor Laboratory Press.

Staskawicz, B., Dahlbeck, D., Keen, N. \& Napoli, C. (1987). Molecular characterization of cloned avirulence genes from race 0 and race 1 of Pseudomonas syringae pv. glycinea. J Bacteriol 169, 57895794.

Stover, C. K., Pham, X. Q., Erwin, A. L., Mizoguchi, S. D., Warrener, P., Hickey, M. J., Brinkman, F. S., Hufnagle, W. O., Kowalik, D. J. \& other authors (2000). Complete genome sequence of Pseudomonas aeruginosa PAO1, an opportunistic pathogen. Nature 406, 959-964.

Tsuge, S., Furutani, A., Fukunaka, R., Kubo, Y. \& Horino, O. (2001). Growth complementation of hrpXo mutants of Xanthomonas oryzae pv. oryzae by virulent strains in rice cultivars resistant and susceptible to the parental strain. J Gen Plant Pathol 67, 51-57.

Tsujimoto, S., Nakaho, K., Adachi, M., Ohnishi, K., Kiba, A. \& Hikichi, Y. (2008). Contribution of the type II secretion system in systemic infectivity of Ralstonia solanacearum through xylem vessels. J Gen Plant Pathol 74, 71-75.

Uematsu, T., Takatsu, A. \& Ohata, K. (1982). A medium for the selective isolation of Pseudomonas cichorii. Ann Phytopathol Soc Jpn 48, 425-432.

Wakimoto, S., Uematsu, T. \& Mukoo, H. (1968). Bacterial canker disease of tomato in Japan. 1. Isolation and identification of the causal bacteria, and resistance of tomato varieties against the disease. Bull Natl Inst Agric Sci Ser C 22, 269-279.

Yamamoto, S., Kasai, H., Arnold, D. L., Jackson, R. W., Vivian, A. \& Harayama, S. (2000). Phylogeny of the genus Pseudomonas: intrageneric structure reconstructed from the nucleotide sequences of gyrB and rpoD genes. Microbiology 146, 2385-2394.

Edited by: C. Boucher 